\title{
Overlap Between Ulerythema Ophryogenes and Keratosis Follicularis Spinulosa Decalvans: a Case Report
}

\author{
Slobodan STOJANOVIĆ ${ }^{1,2^{*}}$, Nada VUČKOVIĆ ${ }^{1,3}$, Marina JOVANOVIĆ ${ }^{1,2}$ \\ 1Faculty of Medicine, University of Novi Sad, Serbia \\ 2Clinic of Dermatovenereology Diseases, Clinical Center of Vojvodina, Novi Sad, Republic of Serbia \\ 3Center of Pathology and Histology, Clinical Center of Vojvodina, Novi Sad, Republic of Serbia \\ *Correspondence: Slobodan STOJANOVIĆ, e-mail: slobodanstojanovicns@sbb.rs \\ DE GRUYTER
OPEN
}

UDC 616.594.8-056.7

\begin{abstract}
Ulerythema ophryogenes and keratosis follicularis spinulosa decalvans are rare folliculocentric keratotic disorders, from the group of follicular genokeratoses, characterized by keratosis pilaris atrophicans: follicular keratotic papules, sometimes with surrounding erythema, which eventually result in fibrosis, atrophy, progressive scarring and permanent hair loss. Ulerythema ophryogenes begins at birth or soon thereafter; it involves the lateral eyebrows, spreads medially and eventually affects the entire eyebrows, cheeks, and less frequently, forehead and asjecebt scalp. Involvement of the scalp has apparently not been reported in cases in which the eyebrows were predominantly involved. In addition to sporadic cases, ulerythema ophryogenes has been reported among relatives. Keratosis follicularis spinulosa decalvans is also a genetically heterogeneous syndrome which begins in infancy or childhood by involving hair bearing skin, especially the scalp; rarely it is confined to the face involving only eyebrows and eyelashes, but affects predominantly the scalp, leading to severe progressive cicatricial alopecia. Both conditions tend to progress until puberty.

The authors present a case of an otherwise healthy 19-year-old male patient, with absence of lateral eyebrows since childhood, which spread symmetrically and medially, until puberty affecting the entire eyebrows, whereas the eyelashes were completely spared. On examination, skin findings on the face, trunk and extremities pointed to ulerythema ophryogenes: apart from hair loss, the lateral eyebrows were highly erythematous; a great number of disseminated follicular, slightly keratotic papules (keratosis pilaris) pin- or match-head sized, were seen on the trunk, extensor surface of the arms and legs, as well as the buttock, and on palpation the skin felt like a "nutmeg grater". However, follicle-based erythematous papules (focal patchy alopecia) were found not only along the eyebrows but also partly in the parietal capillitium forming focal patchy alopecia, which is a finding characteristic for keratosis follicularis spinulosa decalvans; the histopathological analysis of the biopsy specimens taken from the parietal capillitium has confirmed the clinical diagnosis.

Cytogenetic analysis showed no karyotypic abnormalities. Family history showed that the patient's mother and maternal grandfather also suffered from hair loss especially of the lateral eyebrows.

This paper presents an overlap between two rare follicular genokeratoses in a young male with a positive family history, who presented with ulerythema ophryogenes involving not only the eyebrows, but also the scalp, in the form of parietal, focal cicatricial patchy alopecia.
\end{abstract}

\section{Key words}

Eyebrows; Facial Dermatoses; Keratosis; Hair Diseases; Erythema; Skin Diseases, Genetic; Chromosomes, Human, X; Darier Disease

$\mathrm{U}$ lerythema ophryogenes (UO) and keratosis follicularis spinulosa decalvans (KFSD) are rare folliculocentric keratotic disorders, from the group of follicular genokeratoses, characterized by keratosis pilaris atrophicans (KPA): follicular keratotic papules, sometimes with surrounding erythema, which eventually result in fibrosis, atrophy, progressive scarring and permanent hair loss $(1,2,3)$. UO begins 
at birth or soon thereafter; it involves the lateral eyebrows, spreads medially and eventually affects the entire eyebrows, cheeks, and, less frequently extends to the adjacent scalp. Involvement of the scalp has apparently not been reported in cases in which the eyebrows were predominantly involved (4). In addition to sporadic cases, UO has been reported among relatives; it is assumed that in these cases it is transmitted through autosomal dominant inheritance pattern with variable penetrance $(1,2)$.

Keratosis follicularis spinulosa decalvans (KFSD) is also a genetically heterogeneous syndrome characterized also with KPA, but contrary to UO, which particularly and initially, to a greater or lesser extent, affects the eyebrow areas, KFSD usually begins in late infancy or childhood by affecting hair bearing skin, especially the scalp; it is rarely confined to the face involving only eyebrows and eyelashes, but affects predominantly the scalp, leading to severe progressive cicatricial alopecia $(2,3,5)$; an X-linked inheritance has been proposed with random lyonization, because men are more severely affected than women (2). In both conditions progression usually stops after puberty $(2,3)$, and they may show overlapping features and inconclusive, non-diagnostic histopathology $(2,4)$.

The authors present an overlap between two rare follicular genokeratoses in a young male with a positive family history, who presented with UO involving not only the eyebrows, but also the scalp, in the form of parietal, focal cicatricial patchy alopecia.

\section{Case report}

A 19-year-old, otherwise healthy male student, was referred for dermatologic examination due to numerous slightly itchy follicular hyperkeratotic papules surrounded by an erythematous halo, that were confined to the inflamed skin of the parietal scalp and followed by hair loss. The patient had a history of lateral eyebrow loss since infancy, and subsequent development of follicle-based hyperkeratotic papules, $1-2 \mathrm{~mm}$ in diameter, on the trunk and dorsal aspects of the limbs. The family history showed that the patient's mother and maternal grandfather also suffered from hair loss especially of the ateral eyebrows.

On examination, findings indicated UO: apart from lateral eyebrow loss, the eyelashes were completely spared; the skin of the face was highly erythematous; a great number of disseminated follicular, slightly keratotic papules, pin- or match-head sized, were seen on the capillitium, eyebrows, cheeks, trunk, extensor surface of the arms and legs, as well as the buttocks, and on palpation the skin felt like a "nutmeg grater" (Figures 1, 2); follicle-based erythematous papules were found not only along the eyebrows and cheeks, but also partly in the parietal capillitium, with atrophy and alopecia (Figures 3, 4, 5).

Histopathological analysis of the biopsy specimens taken from an area of hair loss on the parietal capillitium, which included follicule-based erythematous papules, revealed dilated hair follicles filled with keratin, infundibular atrophy, perifollicular lymphocytic infiltrates and finally, fibrosis (Figure 6 and 7).

Karyotype: in 11 examined metaphases, $46 \mathrm{XY}$ karyotype was found, without fragile chromosomal sites.

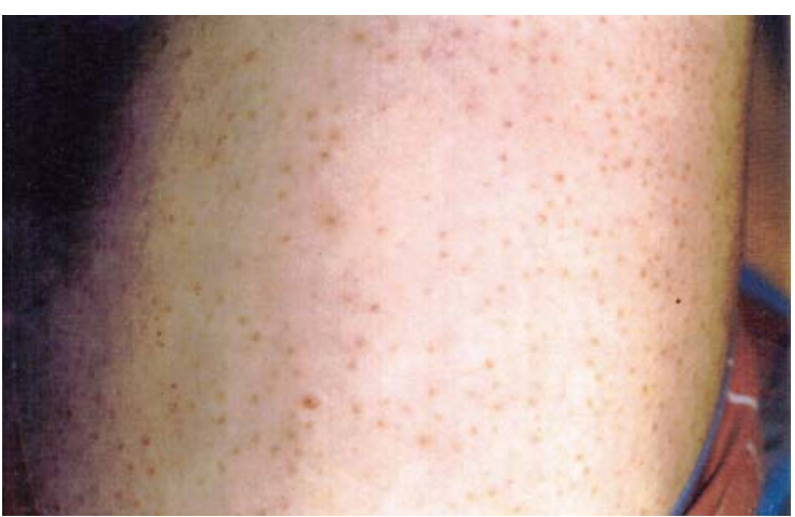

Figure 1. Disseminated follicular, slightly keratotic papules, pin- or match-head sized, on the extensor surface of the arms

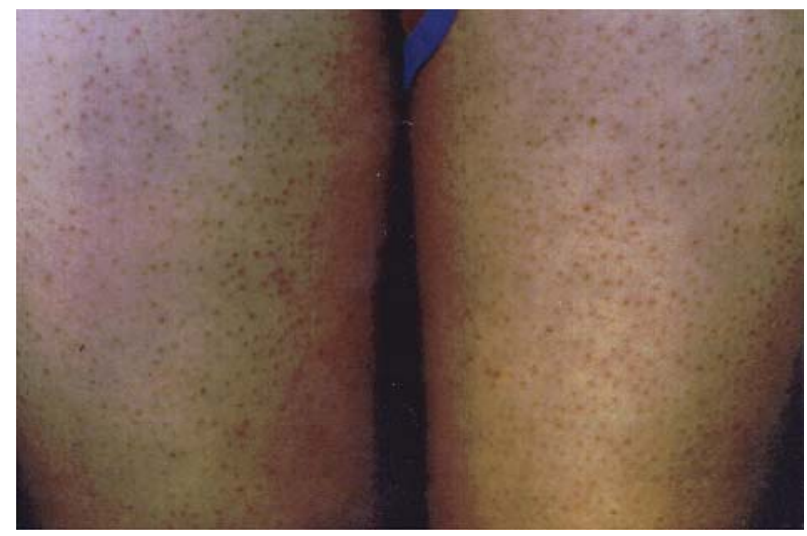

Figure 2. Disseminated follicular, slightly keratotic papules, pin- or match-head sized, on the extensor surface of the arms 


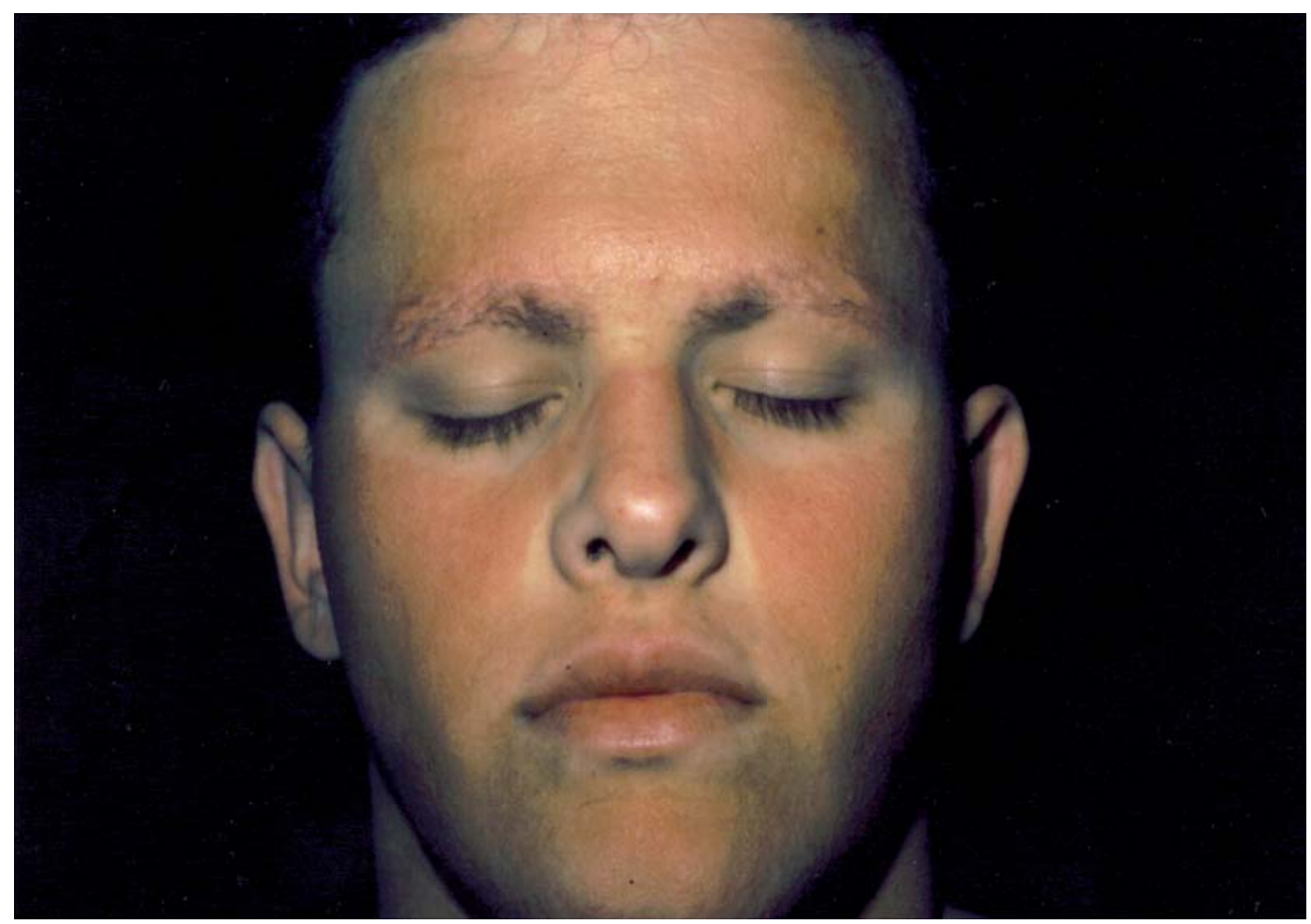

Figure 3. Erythema of the face

Dermatoglyphic findings: normal, unremarkable.

Diagnosis of UO/KPSD overlap was based on history, clinical presentation, course of the disease, and histopathological findings of the biopsy specimens taken from an area of hair loss on the capillitium: changes began in early infancy, predominantly affected the lateral third of the eyebrows, eyelashes were spared, $\mathrm{KP}$ was present on the trunk and dorsal aspects of the limbs, whereas around puberty the patient presented with patchy changes on the parietal capillitium, with follicular keratotic-erythematous papules and atrophy, in the form of parietal, focal cicatricial patchy alopecia.

Therapy included oral doxycycline, $100 \mathrm{mg}$ per day, for initial control of the inflammatory component, combined with a topical steroid, and $2 \%$ salicylic acid in $20 \%$ urea cream.

\section{Discussion}

Keratosis pilaris atrophicans (KPA) is clinically characterized by keratotic follicular papules followed by atrophy, scarring and permanent hair loss. If the pathological process affects hair follicles on the scalp, it results in diffuse scarring alopecia. Keratosis pilaris
(KP) is often present on the trunk and extremities; sometimes it may be associated with conditions such as ichthyosis vulgaris and xerosis $(1,2)$.

Although in cases where signs of the syndrome are incomplete or not clearly expressed, KPA is not easily differentiated from $\mathrm{KP}$, one should take into account that KP (either isolated or associated with atopic dermatitis, vulgar ichthyosis or other ectodermal disorders), causes no follicular destruction, atrophy, scarring or changes on the face and scalp characterized by KPA associated with follicular syndrome with inflammation and atrophy. While hyperkeratosis in $\mathrm{KP}$ is limited to the openings of hair follicles, in KPA it involves the infundibulum and isthmus $=$ and with hypergranulosis represent the first visible histopathological features. Follicular hyperkeratosis cannot be considered the only cause of acute inflammatory changes in the hair follicles (accompanied by simultaneous accumulation of neutrophils and development of intracellular edema in the interfollicular epidermis and papillary dermis), perifollicular arrangement of collagen fibers, accumulation of mucin and mononuclear cells in the 


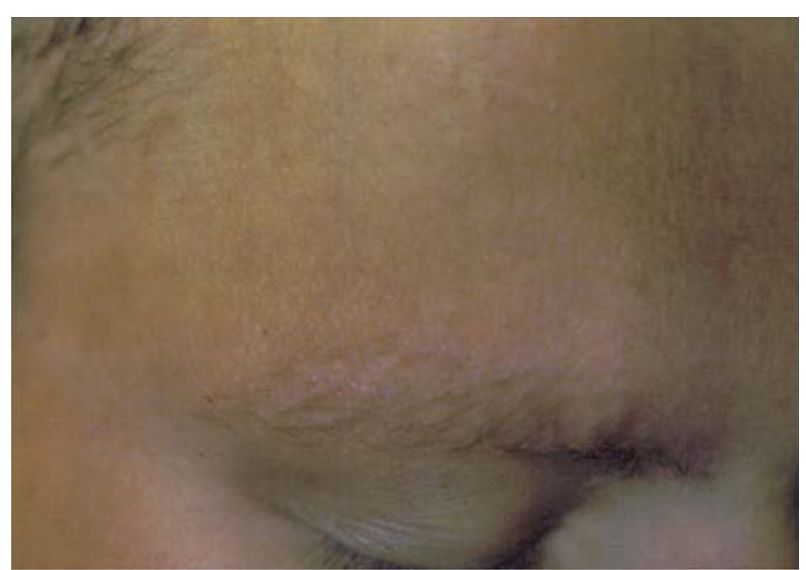

Figure 4. Lateral eyebrow loss, the eyelashes completely spared

final phase of the follicular destruction; it is supposed that unknown etiological factors lead to release of cytokines from follicular keratinocytes, which then induce hyperkeratosis and inflammatory changes $(2,6)$.

Numerous syndromes characterized by KPA have been described. As these syndromes have overlapping features and non-diagnostic histology, as in our case, some authors believe that they represent different stages in the development of the same process (ie. KPA), and that by distribution of changes, severity of inflammation, and the degree of atrophy, they can be classified into one of three existing groups: 1) keratosis pilaris atrophicans faciei (KPAF); 2) atrophoderma vermiculatum (AV); and 3) keratosis follicularis spinulosa decalvans (KFSD) (7). Moreover, AV (synonyms: atrophoderma reticulatum; folliculitis erythematosa reticulata; English honeycomb atrophy; French - Acne vermoulant) is characterized by symmetrical, preauricular small follicular erythematous papules which are quickly followed by atrophic scars and small, pit-like, atrophic areas, irregular in shape and bounded by narrow ridges, giving the cheeks a worm-eaten appearance and may represent an end stage of the preceding two diseases. Another group of authors argues that the $\mathrm{KPAF}, \mathrm{KFSD}, \mathrm{AV}$ and folliculitis spinulosa decalvans (FAD), described by Van Ouch in 1992 (8), are four clearly distinct clinical entities characterized by the presence of keratosis pilaris atrophicans (2, 9). Thus, atrophoderma vermiculatum, as a clearly distinct clinical and pathomorphological entity, may be associated with various syndromes and multiple anomalies, reviewed by Schaller and associates (10).

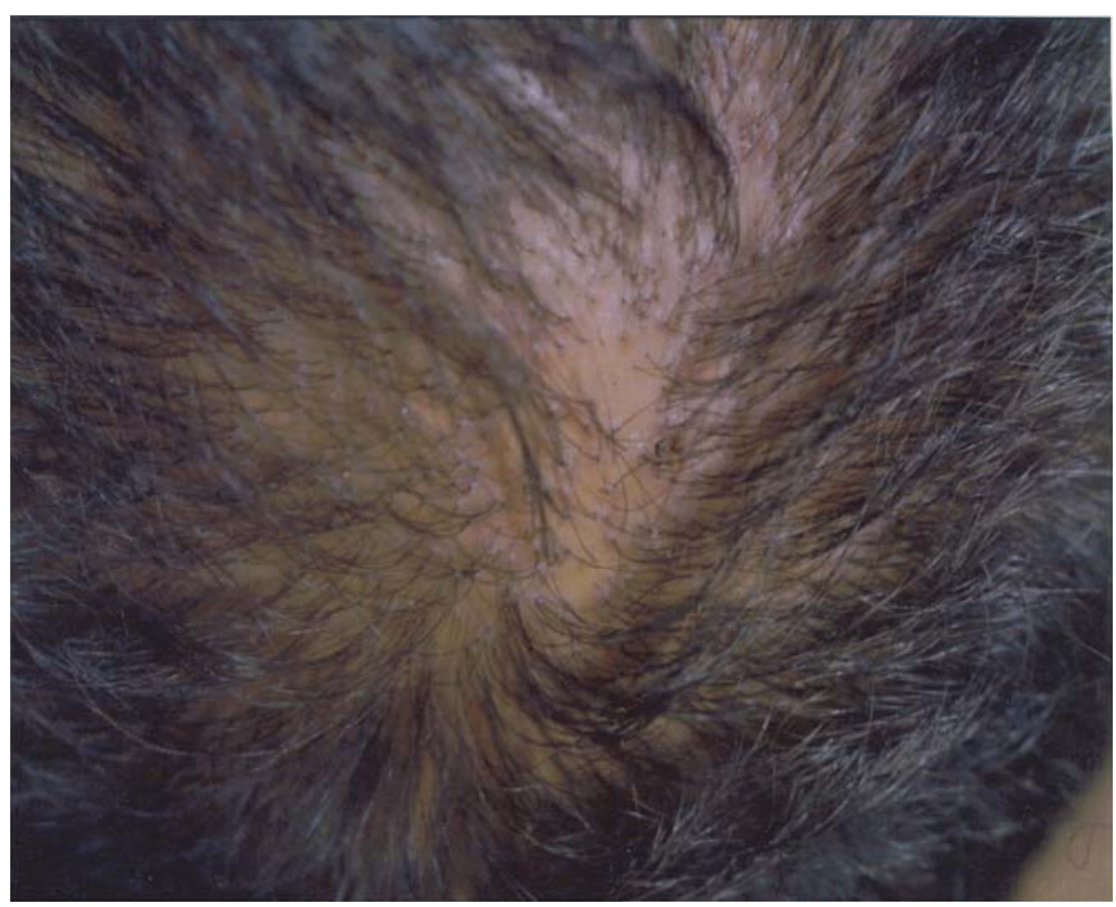

Figure 5. Follicle-based erythematous papules in the parietal capillitium, with scalp showing atrophy and patchy alopecia 


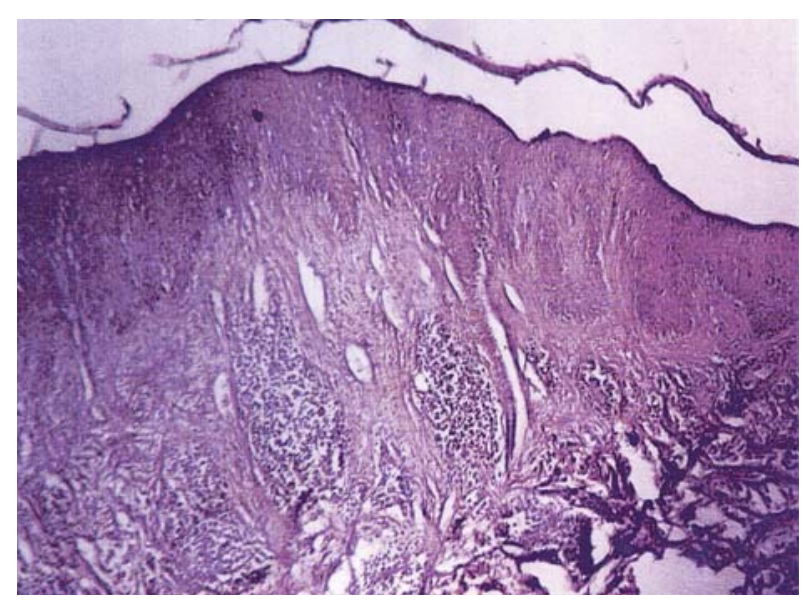

Figure 6. The epidermis is moderately hyperkeratotic, with elongation of rete ridges; some hair follicles are dilated, some show fibrous scarring, surrounded with chronic mononuclear cell infiltrates

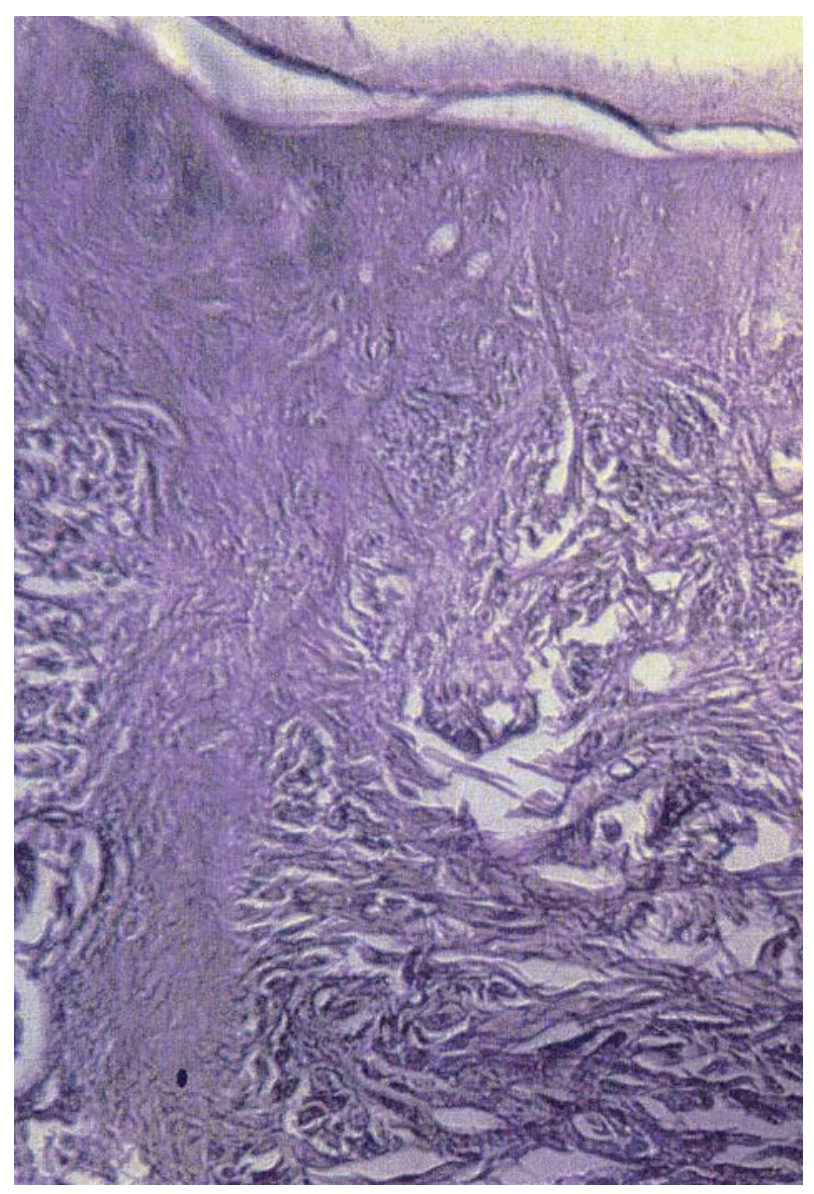

Figure 7. The follicular epithelium has been replaced by fibrous connective tissue; sebaceous glands are missing, and sweat glands are spared keratosis rubra pilaris faciei atrophicans, folliculitis rubra) is derived from the Greek words: ule which means a scar, and ophrys which means eyebrow (3). UO was first described by Erasmus Wilson in 1878 (13). As mentioned previously, scalp involvement with scaring alopecia has not been reported in UO, particularly not in cases where eyebrows were predominantly affected, like in our case. However, there are reports on diagnosed UO cases with alopecia of the scalp; in order to improve diagnostic accuracy, such cases should be reclassified into one of aforementioned conditions (in which alopecia may occur) (4). KFSD initially appears morphologically in relation to KPAF, but with a more extensive pattern of involvement (5). The scaring alopecia in KFSD may be localized or extensive, involving eyebrows and eyelashes (madarosis) as well as the scalp; however, alopecia is typically patchy, such as in our patient, since the process usually does not affect the entire scalp (2). Other features include facial erythema, which was also present in our patient; photophobia, ophthalmitis, and palmar-plantar keratoderma, may also be present, and although characteristic, these features are not pathognomonic for the disease $(2,3)$. KFSD was originally described by Lameris in 1905 , under the name ichthyosis follicularis (IF) (14); the term keratosis follicularis spinulosa decalvans was created by Siemens, in 1926, when he described some individuals from a Bavarian family with keratosis follicularis spinulosa decalvans (15). Most affected families with KFSD show X-linked inheritance: it was found that the gene responsible for KFSD is located on chromosome Xp22.13 - p22.2, mapped between AFM291wf5 and AFM316yf5 (2). Aten and associates investigated patients with KFSD and confirmed mutation in the MBTPS2 gene; it has been established that this mutation decreases the activity of the enzyme involved in the metabolism of cholesterol and the barrier function of the epidermis (16).

The histopathological findings of KFSD depend on the stage of the disease and site of biopsy. Skin biopsies taken from the thorax and extremities show filiform follicular hyperkeratosis, while those taken from the scalp and eyebrows go through four stages: 1) acute or inflammatory stage, where dilated hair follicles are filled with keratin and dystrophic root; follicular epithelium in the isthmus and infundibulum 
show acanthosis, hypergranulosis, hyperkeratosis, in some cases concomitant accumulation of neutrophils and intracellular edema in the hyperkeratotic interfollicular epidermis and papillary dermis; 2) stage with perifollicular accumulation of mononuclear cells, scarce infiltrates containing predominantly lymphocytes and plasma cells, followed by accumulation of perifollicular mucin and thickened collagen fibers, extending parallel with the follicular wall; 3) stage of hair follicle destruction with more or less pronounced granulomatous inflammatory response and increased accumulation of plasma and giant cells ("around the foreign body") directed towards so-called "bare" hair in the dermis and the remaining parts of disintegrated follicles; 4) the final stage which cannot be distinguished from pseudopelade; hair follicles are replaced by fibrous streamers (stelae) (2). These stages were compatible with the findings obtained from the biopsy specimens taken from the parietal scalp with alopecia in our patient.

Apart from histopathology, clinical history and course of the disease, differential diagnosis of certain conditions was helpful in establishing the final diagnosis. The later included the following: 1 . lolliculitis spinulosa decalvans is characterized by persisting inflammation, exacerbation with pustular elements at puberty, when spontaneous improvement occurs in most patients with KFSD; 2. lichen planopilaris is characterized by atrophic scarring on the scalp, dominated by complete absence of follicular openings; adjacent hair follicles at the periphery of lesions, as well as residual hair follicles within the lesions are surrounded by erythematous perifollicular macula and scales; the edge of the area affected by alopeciashows acuminate keratotic plugs; 3 . lichen spinulosus has a predilection for acral areas unlike keratosis pilaris. The horny spine that is characteristic of lichen spinulosus can be removed, leaving behind a tiny funnel-like orifice in the papule, whereas an entire individual lesion can be removed with the plug in keratosis pilaris; 4. Ichthyosis follicularis is present at birth, and is characterized by nonscarring alopecia; histopathologically, unlike KFSD, it presents without fibrosis; 5. Keratosis pilaris atrophicans (KPA) syndrome (keratosis pilaris, alopecia, photophobia or IF, alopecia and photophobia) is also due to mutations on MBTPS2 gene on chromosome Xp21.2 - p22.2, so it can be assumed that KAP syndrome and KFSD represent overlap within the spectrum of phenotypes of the same genetic disorder, but alopecia in KAP syndrome is always nonscarring, unlike in KFSD (17).

In most cases the process resolves by puberty, but the consequences are permanent. The therapy is symptomatic, and there is no specific effective treatment: retinoids (isotretinoin, acitretin) should be used only during the active phase of the disease, which means in the early childhood. Hair loss is permanent, and treatment in the chronic phase, ie. after puberty, which is by far the most common case, only alleviates the existing hyperkeratotic changes. Antibiotic treatment should be carried out only in periods of acute exacerbation, which is manifested by erythema and scarce pustules on the scalp. Biopsy specimens may show Staphylococcus aureus, and the treatment should be carried out according to the antibiogram. Topical steroids and keratolytics may partially improve the symptoms, but after cessation of therapy, the benefits are lost. Tretinoin ( $0.1 \%$ cream once daily), may induce or aggravate the existing erythema, that can be avoided by concomitant use of corticosteroid creams (once or twice a day), or topicalretinoic acid $0.025 \%$ on alternate days for the scalp at night. Hair removal with a long-pulse Q-switched ruby laser has been found to be useful in progressive orrecalcitrant KFSD. Atrophic lesions may be treated with dermabrasion and/or application of collagen implants, now considered to be the most successful treatment modality. Ablative laser skin resurfacing is done using ultrapulse $\mathrm{CO} 2$ or YAG (yttrium aluminum garnet) laser (2). A significant erythema reduction is achieved by using $585 \mathrm{~nm}$ pulsed dye laser (18).

\section{Conclusion}

The authors present an overlap between two rare follicular genokeratoses in a young male with a positive family history, who presented with ulerythema ophryogenes involving not only the eyebrows, but also the scalp, in the form of parietal, focal cicatricial patchy alopecia.

\section{Abbreviations}

UO - ulerythema ophryogenes

KFSD - keratosis follicularis spinulosa decalvans

$\mathrm{KPA}$ - keratosis pilaris atrophicans 
AV - atrophoderma vermiculatum

FSD - folliculitis spinulosa decalvans

IF - ichthyosis follicularis

KAP - keratosis pilaris, alopecia, photophobia

YAG - yttrium aluminium garnet

PDL - pulsed dye laser $(585 \mathrm{~nm})$

\section{References}

1. Judge MR, McLean WH, Munro CS. Disorders of keratinization. In: Burns T, Breathnach S, Cox N, Griffiths C, editors. Rook's textbook of dermatology. $8^{\text {th }}$ ed. Oxford: Blackwell Publishing Ltd; 2010. p. 19.1-19.122.

2. Mirmirani P, Rogers M. Keratosis pilaris and other inflammatory follicular keratotic syndromes. In: Goldsmith LA, Katz SI, Gilchrest BA, Paller AS, Leffell DJ, Wolff K, editors. Fitzpatrick's dermatology in general medicine. $7^{\text {th }}$ ed. New York: McGraw-Hill; 2008. p. 749-53.

3. Arnold AW, Buechner SA. Keratosis pilaris and keratosis pilaris atrophicans faciei. J Dtsch Dermatol Ges 2006;4:319-23.

4. Messenger AG, de Berker DA, Sinclair RD. Disorders of hair. In: Burns T, Breathnach S, Cox N, Griffiths C, editors. Rook's textbook of dermatology. $8^{\text {th }}$ ed. Oxford: Blackwell Publishing Ltd; 2010. p. 66.1-66.100.

5. Khumalo NP, Loo WJ, Hollowood IS, Salvary I, Graham RM, Dawber RPR. Keratosis pilaris atrophicans in mother and daughter. J Eur Acad Dermatol Venereol 2002;16:387-400.

6. Sequeira FF, Jayaseelan E. Keratosis follicularis spinulosa decalvans in a female. Indian J Dermatol Venereol Leprol 2011;77:325-7.

7. Di Lernia V, Ricci C. Folliculitis spinulosa decalvans: an uncommon entity within the keratosis pilaris atrophicans spectrum. Pediatr Dermatol 2006;23(3):255-8.
8. Van Osch LD, Oranje AP, Keukens FM, van Voorst Vader PC, Veldman E. Keratosis follicularis spinulosa decalvans: a family study of a seven male cases and female carriers. J Med Genet 1992;29:36-40.

9. Callaway SR, Lesher JL Jr. Keratosis pilaris atrophicans: case series and review. Pediatr Dermatol 2004;21:14-7.

10. Schaller J, Rytina E, Rutten A, Hendricks C, Ha T, Requena L. Sweat duct proliferation associated with aggregates of elastic tissue and atrophodermia vermiculata: a simulator of microcystic adnexal carcinoma. Report of two cases. J Cutan Pathol 2010:37:1002-9.

11. Guidry JA, Rees A, Chan AJ, Shuja F, Hsu S. Ulerythema ophryogenes and Noonan syndrome. Dermatol Online J 2013;19(2):14.

12. Liakou AI, Esteves De Carvalho AV, Nazarenko LP. Trias of keratosis pilaris, ulerythema ophryogenes and 18p monosomy: Zouboulis syndrome. J Dermatol 2014;41:371-6.

13. Wilson E. Lectures on dermatology. London: J \& A. Churchill; 1878.

14. Lameris HJ. Ichthyosis follicularis. Ned Tijdschr Geneeskd 1905;41:1524.

15. Siemens HW. Keratosis follicularis spinulosa decalvans. Arch Dermatol Syphilol 1926;151:384-7.

16. Aten E, Brasz LC, Bornholdt D, Hooijkaas IB, Porteous ME, Sybert VP, et al. Keratosis follicularis spinulosa decalvans is caused by mutations in MBTPS2. Hum Mutat 2010;31:1125-33.

17. Oeffner F, Martinez F, Schaffer J, Salhi A, Monfort S, Oltra $S$, et al. Intronic mutations affecting splicing of MBTPS2 cause ichthyosis follicularis, alopecia and photophobia (IFAP) syndrome. Exp Dermatol 2011;20:445-56.

18. Alcantara Gonzalez J, Boixeda P, Truchuelo Diez MT, Fleta Asin B. Keratosis pilaris rubra and keratosis pilaris atrophicans faciei treated with pulsed dye laser: report of 10 cases. J Eur Acad Dermatol Venereol 2011;25:710-4.

\section{Ulerythema ophryogenes i keratosisfollicularisspinulosa decalvans - prikaz slučaja}

\section{Sažetak}

Ulerythema ophryogenes (UO) i keratosis follicularis spinulosa decalvans (KFSD) predstavljaju retke folikulocentrične keratotične poremećaje, koji pripadaju grupi folikularnih genokeratoza, u kojima dominira keratosis pilaris atrophicans (KPA): folikularno smeštene keratotične papule okružene manje ili više izraženim eritemom koje vremenom zamenjuje fibroza, atrofija, progresivno ožiljavanje i trajni gubitak dlake. Proces kod ulerythema ophryogenes započinje u prvim mesecima života i zahvata lateralne strane obrva, širi se medijalno, može zahvatiti obrve u celini i znatno ređe proširiti se na čelo i susedni deo kapilicijuma. Zahvatanje kapilicijuma nije karakteristično za ulerythema ophryogenes, naročito ne za slučajeve u kojima kliničkom slikom dominiraju promene na obrvama. Pored sporadičnih slučajeva, opisana je i pojava ulerythema ophryogenes među srodnicima, pretpostavlja se da se u ovim slučajevima bolest prenosi autozomno dominantno sa varijabilnom penetracijom. Keratosis follicularis spinulosa decalvans takođe je heterogeni genetski sindrom za koji je karakteristična keratosis pilaris atrophicans, ali za razliku od ulerythema ophryogenes koji od samog početka zahvata manje ili više obrve, keratosis follicularis spinulosa decalvans obično započinje kasnije, u ranom detinjstvu i karakteristično zahvata kapilicijum, dovodeći u težim oblicima do progresivne ožiljne alopecije. Pretpostavlja se da se 
nasleđuje vezano za X-hromozom sa randominiziranom lajonizacijom, s obzirom da se bolest ispoljava sa znatno težim znacima kod osoba muškog pola u odnosu na žene. Kod ulerythema ophryogenes i keratosis follicularis spinulosa decalvans evolucija bolesti se u najvećem broju slučajeva zaustavlja u vreme puberteta, klinički znaci se međusobno mogu preklapati i biti istovremeno prisutni kod jednog istog pacijenta, a rezultati patohistološke analize ostati bez diferencijalno-dijagnostičkog značaja.

Autori prikazuju overlap dve retkefolikularnegenokeratoze. Prikaz slučaja. Devetnaestogodišnji mladić, inače dobrog zdravstvenog stanja, upućen je na pregled dermatologu zbog pojave brojnih folikularnih hiperkeratotičnih papula okruženih eritematoznim haloom u parijetalnom delu kosmatog dela glave. Promene su bile praćene blagim osećajem svraba, skoncentrisane na jednom relativno jasno ograničenom ovalnom polju na kome je dlaka nedostajala a koža pokazivala znake inflamacije. Pacijent je dao podatak da su mu spoljašnji delovi obrva nedostajali od najrananijih meseci života, a da su mu se kasnije na trupu i ekstremitetima počeli javljati čvrsti, orožali čvorići veličine čiodine glavice 1-2 $\mathrm{mm}$ u prečniku.

Analizom pedigrea se došlo do podatka da su spoljašnji delovi obrva nedostajali kod pacijentove majke i njenog oca. Prilikom objektivnog pregleda, nalaz je ukazivao na ulerythema ophryogenes: pored nedostatka dlaka, $\mathrm{u}$ lateralnim polovinama, obrva trepavice su bile potpuno pošteđene; koža je bila izrazito eritematozna; na kapilicijumu, obrvama, obrazima, na trupu i pretežno na ekstenzornim stranama ruku i nogu kao i na gluteusima, bio je prisutan veći broj diseminovanih folikularno smeštenih i lako keratotičnih papula veličine glavice čiode do šibice, koje su na palpaciju odavale utisak „trenice“ (slike 1 i 2); duž obrva, obraza i na parijetalnom kapilicijumu nalazile su se folikularne eritematozne papule smeštene na eritematoznoj koži sa atrofijom i alopecijom (slike 3-5).

Patohistološka analiza isečka uzetog sa alopecijskog polja na parijetalnom kapilicijumu koji je obuhvatio i folikularno smeštene eritematozne papule, pokazala je proširene otvore dlačnih folikula ispunjene keratinom, atrofiju infundibularnog dela folikuluma i perifolikularni limfocitni infiltrat (slike 6 i 7).

Dijagnoza ulerythema ophryogenes/follicularis spinulosa decalvans overlap je postavljena na osnovu anamneze kliničke slike, toka oboljenja i patohistološkog nalaza u isečku kože uzete sa regije koju je zahvatila alopecija u parijetalnom kapilicijumu: promene započele u prvim mesecima života, dominantno zahvatile lateralne trećine obrva, trepavice ostale očuvane; po trupu prisutna KP; $\mathrm{u}$ vreme puberteta pojavila se jasno ograničena solitarna promena na kapilicijumu sa folikularnim keratotičnoeritematoznim papulama, atrofijom, $\mathrm{u}$ formi parijetalne, fokalne ožiljne alopecije.

Inicijalno je u terapiju uveden doksiciklin u dozi od 100 mg dnevno sa ciljem kontrole inflamacije, u kombinaciji sa topijskim kortikosteroidnim preparatom, 2\% salicilnom kiselinom i kremom sa 20\% uree.

Diskusija. Keratosis pilaris atrophicans klinički se manifestuje folikularno smeštenim keratotičnim papulama koje postepeno zamenjuju znaci atrofije, ožiljavanje i trajni gubitak dlake. Ukoliko su patološkim procesom zahvaćeni dlačni folikuli u kapilicijumu, nastaje difuzna ožiljna alopecija. Keratosis pilaris često je prisutna na trupu i ekstremitetima; lako se u slučajevima u kojima su znaci sindroma nepotpuni ili nedovoljno jasno izraženi keratosis pilaris atrophicans teško razlikuje od keratosis pilaris, treba znati da keratosis pilaris (bilo izolovana ili udružena sa atopijskim dermatitisom, vulgarnom ihtiozom ili drugim ektodermnim poremećajima) ne izaziva destrukciju folikula, atrofiju, ožiljavanje, niti promene na licu i poglavini koje karakterišu keratosis pilaris atrophicans u sastavu folikularnih sindroma sa inflamacijom i atrofijom. Hiperkeratoza kod keratosis pilaris ograničena je na otvore dlačnih folikula, dok u keratosis pilaris atrophicans ona zahvata infundibulum $\mathrm{i}$ istmus $\mathrm{i}$, uz hipergranulozu, predstavlja prvu vidljivu patohistološku promenu. Folikularna hiperkeratoza se ne može smatrati jedinim uzrokom akutnih zapaljenskih promena $\mathrm{u}$ folikulu (praćenih istovremenim nakupljanjem neutrofila i razvojem intercelularnog edema $u$ interfolikularnom epidermisu i papilarnom dermisu), zatim perifolikularnog umnožavanja kolagenih vlakana, nakupljanja mucina i mononuklearnih ćelija i u završnoj fazi destrukcijom dlačnog folikula: pretpostavlja se da za sada nepoznati etiološki faktor dovodi do oslobađanja citokina iz folikularnih keratinocita i da oslobođeni citokini izazivaju hiperkeratozu i inflamacijske promene koje potom slede.

Opisani su brojni sindromi koje karakteriše prisustvo keratosis pilaris atrophicans. S obzirom da ovi sindromi imaju overlapping features and non-diagnostic histology as in our case, neki autori smatraju da oni predstavljaju različite faze u razvoju jednog istog procesa (tj. keratosis pilaris atrophicans), a da se na osnovu distribucije promena, jačine inflamacije i stepena nastale atrofije, oni mogu svrstati u jednu od tri postojeće grupe koje 
čine: 1) keratosis pilaris atrophicans faciei - KPAF (sinonim ulerythema ophriogenes - UO); 2) atrophoderma vermiculatum (AV); i 3) keratosis follicularis spinulosa decalvans (KFSD). Štaviše, AV (sinonimi: atrophoderma reticulatum; folliculitis ulerythematosa reticulata; engl. honeycomb atrophy; franc. acne vermoulant), za koju su karakteristične simetrične, preaurikularno lokalizovane, male folikularno smeštene eritematozne papule koje brzo zamenjuju atrofisana ožiljna polja i mnogobrojna gusto raspoređena rupičasta, okruglasta ovalna ili nepravilna ulegnuća razdvojena uskim sjajnim beličastim tračcima, koja daju obolelim obrazima izgled drveta izjedenog crvima, može predstavljati završni stadijum prethodna dva oboljenja. Druga grupa autora zastupa stav da KPAF, KFSD, AV i folliculitis spinulosa decalvans (FSD) predstavljaju četiri jasno odvojena klinička entiteta koje zajednički karakteriše prisustvo keratosis pilaris atrophicans. KPAF se smatra markerom za određene sindrome, kao što je npr. Zouboulis sy. za koji je karakteristično prisustvo trijasa: KP, KPAF i 18p monosomija.

Naziv ulerythema ophryogenes (UO), (sinonimi: keratosis pilaris atrophicans faciei, keratosis rubra pilaris faciei atrophicans, folliculitis rubra) potiče od grčke reči ule, što na engleskom znači scar, i od grčke reči ophrys što na engleskom znači eyebrow. Ulerythema ophryogenes prvi je opisao Erazmus Vilson (Erasmus Wilson) 1878. godine. Kao što je to ranije istaknuto, zahvatanje kapilicijuma nije karakteristično za UO, naročito ne za slučajeve u kojima kliničkom slikom dominiraju promene na obrvama. Zato treba korigovati dijagnozu u onim slučajevima ulerythema ophryogenes u kojima se javila alopecija. Keratosis follicularis spinulosa decalvans i ulerythema ophryogenes mogu u samom početku izazvati slične morfološke promene, ali je tok oboljenja u KFSD znatno progresivniji i teži. Ožiljna alopecija koja se javlja u KFSD može biti lokalizovana ili opsežnija, sa zahvatanjem obrva, trepavica (madarosis) i naročito kapilicijuma; karakteristično je da alopecijom bude obuhvaćen ograničen deo kapilicijuma kao što je to bio slučaj kod našeg pacijenta sa parijetalnom fokalnom cikatricijelnom alopecijom. Na licu može kao u našem slučaju, biti prisutan eritem; fotofobija, oftalmitis, palmo-plantarna keratodermija mogu biti prisutni u pojedinim slučajevima ali nisu osobine patognomonične za oboljenje. Keratosis follicularis spinulosa decalvans se prenosi u vezi sa X-hromozomom: utvrđeno je da se gen odgovoran za nastanak oboljenja nalazi na Xp 22.13 - p22.2 i to na mestu koje je na hromozomskoj mapi označeno od AFM291wf5 do AFM316yf5. Ispitivanjima koje je vršio Aten sa saradnicima, kod osoba obolelih od KFSD dokazano je prisustvo mutacija u MBTPS2 genu; utvrđeno je da navedena mutacija izaziva smanjenje aktivnosti enzima uključenog $\mathrm{u}$ metabolizam holesterola i barijernu funkciju epidermisa. Patohistološki nalaz u KFSD zavisi od trajanja oboljenja i od mesta sa kog je uzeta biopsija. Promene keratosis pilaris $u$ isečku kože uzete $s$ trupa ili ekstremiteta pokazuju filiformnu folikularnu hiperkeratozu), dok one u koži obrva i kapilicijuma prolaze kroz četiri razvojne faze: 1) u akutnoj ili inflamacijskoj fazi, dilatirani dlačni folikuli ispunjeni su keratinom i distrofisanim dlakama, folikularni epitel u istmusu i infundibulumu pokazuje akantozu, hipergranulozu, hiperkeratozu, a u pojedinim slučajevima istovremeno nakupljanje neutrofila i intercelularni edem u hiperkeratotičnom interfolikularnom epidermisu i papilarnom dermisu; 2) u fazi perifolikularnog nakupljanja mononuklearnih ćelija, stvaranje oskudnih infiltrata sastavljenih pretežno od limfocita i manjeg broja plazmocita, praćeno je perifolikularnim nakupljanjem mucina i zadebljalih kolagenskih vlakana koja se protežu paralelno sa zidom folikula; 3) fazu destrukcije dlačnih folikula prati manje ili više izražena granulomatozna inflamacijska reakcija s većim nakupljanjem plazma ćelija i džinovskih ćelija tipa „oko stranog tela“" usmerenih na tzv. "gole“ dlake u dermisu i na preostale delove dezintegrisanih folikula; 4) u završnoj fazi koja se ne može razlikovati od one kod pseudopelade, dlačne folikule zamenjuju fibrozni stubovi tzv. stelae. These were compatibile with the finding obtained from the biopsy taken from the parietal alopecic scalp in our patient.

Diferencijalna dijagnoza ima često dijagnostički značaj i podrazumeva isključivanje sledećeg: 1. za folliculitis spinulosa decalvans karakteristična je značajno izraženija inflamacija, pogoršanje i pojava pustula $u$ kapilicijumu u periodu puberteta, kada kod najvećeg broja obolelih $s$ keratosis follicularis spinulosa decalvans započinje spontano poboljšanje; 2 . za lichen planopilaris karakteristične su atrofične ožiljne plaže na kapilicijumu na kojima dominira potpuno odsustvo, tj. gubitak folikularnih otvora; susedni dlačni folikuli po obodu lezija kao i rezidualni dlačni folikuli unutar same lezije okruženi su perifolikularnim eritematoznim makulama i skvamama, po ivicama delova zahvaćenih alopecijom, vidljivi su akuminirani keratotični čepovi; 3. lichen spinulosus pokazuje predilekciju za akralnu lokalizaciju za razliku od keratosis pilaris. Orožali sadržaj koji je po 
svom izgledu karakterističan za lichen spinulosus može se lako odstraniti, pri čemu na njegovom mestu na papuli zaostaje prostor nalik na levak, dok kod KP zajedno sa keratinskim čepom biva odstranjena lezija u celini; 4. ichthyosis follicularis (IF) je prisutna na rođenju, karakteriše je neožiljna alopecija, u patohistološkom nalazu za razliku od keratosis follicularis spinulosa decalvans nema fibroze; 5. KAP sindrom (keratosis pilaris, alopecia, photophobia s. IF, alopecia i fotofobija) takođe je posledica mutacija u MBTPS2 genu na hromozomu Xp22, pa se može pretpostaviti da KAP sindrom i keratosis follicularis spinulosa decalvans predstavljaju overlap unutar spektra fenotipova jednog istog genetskog poremećaja ali je alopecija u KAP sindromu za razliku od keratosis follicularis spinulosa decalvans uvek neožiljna.

Proces se u najvećem broju slučajeva zaustavlja tokom puberteta ali su posledice trajne. Lečenje je isključivo simptomatsko, specifična terapija ne postoji: retinoide (izotretinoin, acitretin) treba primenjivati samo u vreme aktivne faze oboljenja, što znači u ranom detinjstvu. Gubitak kose, odnosno dlaka je trajan, i svako lečenje $\mathrm{u}$ hroničnoj, stacionarnoj fazi, tj. posle puberteta, što je do sada bio najčešći slučaj, može samo ublažiti postojeće hiperkeratotične promene. Lečenje antibioticima treba sprovoditi samo u periodima akutnog pogoršanja, koje se kod manjeg broja obolelih manifestuje pojavom eritema i malog broja pustula na koži poglavine. Iz brisa promena može se izolovati Staphyloccocus aureus, a lečenje treba sprovesti prema antibiogramu. Lokalna primena keratolitika i kortikosteroida dovodi samo do delimičnog poboljšanja, a po prestanku lečenja njihov efekat se gubi. Tretinoin ( $0,1 \%$ krem jedanput dnevno), može izazvati na koži pojavu ili pogoršanje već postojećeg eritema, što se može izbeći istovremenom primenom kortikosteroidnih kremova (jedanput do dvaput dnevno), ili 0,025\% retinoične kiseline na kapilicijum alternativno svake druge noći. Uklanjanje dlaka uz pomoć rubi lasera (engl. long-pulse non-Qswitched ruby laser) pokazalo se efikasno u rekalcitrantnim progresivnim slučajevima KFSD. Atrofične promene mogu se lečiti dermobrazijom i/ili primenom kolagenih implantata što se danas smatra najuspešnijim metodom lečenja, a za izravnavanje površine kože mogu se primeniti ultrapulsni $\mathrm{CO}_{2}$ ili YAG (yttrium aluminium garnet) laser. Značajno smanjenje eritema se može postići pomoću PDL lasera (engl. pulsed dye laser at $585 \mathrm{~nm}$ ). Zaključak. Autori su prikazali overlap dve retke folikularne genokeratoze u slučaju mlade osobe muškog pola sa pozitivnom porodičnom anamnezom, kod koje je erythema ophryogenes, pored obrva, zahvatio i poglavinu $\mathrm{u}$ formi parietal, focal patchy cicatricial alopecia.

\section{Ključne reči}

Obrve; Dermatoze lica; Keratoza; Bolesti dlake; Eritem; Genetske kožne bolesti; Humani hromozom X; Darierova bolest 